\title{
OPEN Agriculture increases the bioavailability of silicon, a beneficial element for crop, in temperate soils
}

\author{
M. Caubet ${ }^{1}$, S. Cornu ${ }^{2}$, N. P. A. Saby ${ }^{1}$ \& J.-D. Meunier ${ }^{2}$
}

Crops may take benefits from silicon (Si) uptake in soil. Plant available Si (PAS) can be affected by natural weathering processes or by anthropogenic forces such as agriculture. The soil parameters that control the pool of PAS are still poorly documented, particularly in temperate climates. In this study, we documented PAS in France, based on statistical analysis of $\mathrm{Si}$ extracted by $\mathrm{CaCl}_{2}\left(\mathrm{Si}_{\mathrm{CaCl}}\right)$ and topsoil characteristics from an extensive dataset. We showed that cultivation increased $\mathrm{Si}_{\mathrm{CaCl} 2}$ for soils developed on sediments, that cover $73 \%$ of France. This increase is due to liming for non-carbonated soils on sediments that are slightly acidic to acidic when non-cultivated. The analysis performed on non-cultivated soils confirmed that $\mathrm{Si}_{\mathrm{CaCl}}$ increased with the $<2 \mu \mathrm{m}$ fraction and pH but only for soils with a $<2 \mu \mathrm{m}$ fraction ranging from 50 to $325 \mathrm{~g} \mathrm{~kg}^{-1}$. This increase may be explained by the $<2 \mu \mathrm{m}$ fraction mineralogy, i.e. nature of the clay minerals and iron oxide content. Finally, we suggest that $4 \%$ of French soils used for wheat cultivation could be deficient in $\mathrm{Si}_{\mathrm{CaCl} 2}$.

Silicon ( $\mathrm{Si}$ ) has been shown to be beneficial for crops exposed to biotic or abiotic stresses ${ }^{1-5}$. The role of $\mathrm{Si}$ remains controversial ${ }^{1,6}$, but crop yields may depend on the bioavailable $\mathrm{Si}$ in the soil ${ }^{7}$, particularly for globally cultivated crops and staple food that contain $1 \%$ or more Si by dry weight such as rice, sugar cane, or wheat, or more broadly, the Poaceae ${ }^{8-10}$. Soil Si bioavailability is therefore an emerging issue in agriculture, as Si fertilization of soil depleted of bioavailable Si could increase yields ${ }^{8,11-13}$.

$\mathrm{Si}$ is taken up from the soil solution by roots and is accumulated in the shoots in the form of amorphous silica particles (phytoliths). In the soil solution, dissolved $\mathrm{Si}\left(\mathrm{DSi}\right.$ ) primarily occurs in the neutral form $\mathrm{Si}(\mathrm{OH})_{4}$ (silicic acid). The DSi concentration typically ranges from 0.1 to $0.6 \mathrm{mmol} \mathrm{L}^{-13}$. DSi originates from the dissolution of primary and secondary silicate minerals through alteration or chemical weathering ${ }^{14}$ and from plant recycling through the dissolution of phytoliths ${ }^{15,16}$. The alterability of silicate minerals can be characterized by their solubility and kinetic properties, which are dependent upon temperature, $\mathrm{pH}$, and available solutes ${ }^{17,18}$.

DSi concentration in the soil solution can be lowered by plant uptake ${ }^{19}$, uptake by silica-shelled microorganism $\mathrm{s}^{20}$ and $\mathrm{Si}$ adsorption to mineral surfaces ${ }^{21}$. Quantifying the pool of Si that is bioavailable (PAS) is still a challenge ${ }^{7}$. Si extracted with $\mathrm{CaCl}_{2}\left(\mathrm{Si}_{\mathrm{CaCl} 2}\right)$, acetate, acetic acid, or citrate are used as PAS proxies since the concentrations extracted by these reagents are proportional to plant Si concentration or grain yield ${ }^{22,23}$. PAS concentrations extracted by these reagents have been shown to be positively correlated with soil properties such as phytolith content ${ }^{24}, \mathrm{pH}^{25-27},<2 \mu \mathrm{m}$ fraction ${ }^{7,28}$, organic matter, and iron oxides ${ }^{28}$. A negative correlation between PAS and total Si content has also been documented, reflecting the predominance of low solubility minerals such as quartz in the Si pool ${ }^{28,29}$. Critical levels of PAS have been identified in cultivated lands mainly under tropical climate including the paddy soils of $\mathrm{Asia}^{7,30}$, the USA ${ }^{31}$, and Brazil ${ }^{32}$, and the sugarcane fields of Australia $^{33}$. Under critical levels of PAS, silicate fertilization may be recommended and is already applied on tropical soils in some countries.

Chemical weathering leads to a removal of Si through leaching and erosion ${ }^{14}$. Intense weathering causes soils to become acidic and depleted in bases and Si (desilication) due to loss of primary silicates that are easily weatherable. Cultivation, through exportation of crops containing silicon has been indicated as a Si pool modifier by lowering the phytolith pool $^{34-39}$; as a consequence, cultivation may reduce the soil Si availability if plant residues are not returned to the fields ${ }^{40}$. Darmawan et al. ${ }^{11}$ documented a significant decrease of available Si after approximately 30 years of intensive rice cultivation in Indonesia. The decrease of PAS in soil has been listed as a

${ }^{1}$ INRAE, Infosol, US 1106, Orléans, France. ${ }^{2}$ Aix-Marseille Univ, CNRS, IRD, Coll de France, INRAE, CEREGE, Aix-en-Provence, France. ${ }^{\bowtie}$ email: sophie.cornu@inrae.fr 


\begin{tabular}{|c|c|c|c|c|c|c|c|}
\hline \multirow[b]{2}{*}{ Soil parent material/type } & \multirow[b]{2}{*}{ Land use } & \multicolumn{5}{|c|}{$\mathrm{Si}_{\mathrm{CaCl} 2}\left(\mathrm{mg} \mathrm{kg}^{-1}\right)$} & \multirow[b]{2}{*}{$\mathbf{n}$} \\
\hline & & Mean & Sd & Q25 & Q50 & Q75 & \\
\hline \multirow{3}{*}{ Carbonated soils on sediment } & All & 31 & 17 & 20 & $26^{\mathrm{a}}$ & 36 & 516 \\
\hline & Non-cultivated & 25 & 11 & 17 & 23 & 30 & 219 \\
\hline & Cultivated & 35 & 20 & 23 & 29 & 41 & 297 \\
\hline Soils on igneous extrusive rock & All & 51 & 27 & 32 & $47^{\mathrm{b}}$ & 66 & 29 \\
\hline \multirow{3}{*}{ Soils on igneous intrusive rock } & All & 11 & 5.7 & 8.6 & $10^{c}$ & 13 & 155 \\
\hline & Non-cultivated & 12 & 6.1 & 8.8 & 11 & 14 & 109 \\
\hline & Cultivated & 10 & 4.2 & 7.6 & 9.3 & 11 & 46 \\
\hline \multirow{3}{*}{ Soils on metamorphic rock } & All & 11 & 5.8 & 7.8 & $9.6^{c}$ & 13 & 217 \\
\hline & Non-cultivated & 11 & 5.8 & 7.5 & 9.5 & 13 & 120 \\
\hline & Cutivated & 12 & 5.9 & 8.1 & 9.7 & 14 & 97 \\
\hline \multirow{3}{*}{ Non-carbonated soils on sediment } & All & 20 & 15 & 9.2 & $16^{\mathrm{d}}$ & 28 & 1013 \\
\hline & Non-cultivated & 16 & 13 & 7.9 & 12 & 21 & 537 \\
\hline & Cultivated & 25 & 16 & 12 & 23 & 34 & 476 \\
\hline Podzols & All & 5.1 & 2.8 & 3.7 & $4.2^{\mathrm{e}}$ & 4.9 & 56 \\
\hline \multicolumn{2}{|l|}{ All data (subset 1) } & 21 & 16 & 9.5 & 17 & 28 & 1986 \\
\hline
\end{tabular}

Table 1. Summary statistics of $\mathrm{Si}_{\mathrm{CaCl} 2}$ concentrations measured for the subset 1 (Supplementary Table S1). The summary statistics are provided for the combination of a parent material group and land use. Q25, Q50, and Q75 are the 25\%,50\%, and 75\% percentile, respectively. Medians sharing a letter are not significantly different according to pairwise comparisons of Wilcoxon test with Tukey adjustment for multiple comparisons.

factor contributing to the stagnation of crop yields ${ }^{12}$. Si supply is considered a useful strategy for improving crop health ${ }^{7}$, the influence of land use and agricultural practices on PAS has become an emerging issue ${ }^{41}$.

The objectives of this paper are to determine the impact of agriculture on PAS in temperate soils. To do so we (i) estimated the spatial variability of PAS in France, a country with a high soil diversity ${ }^{42}$ that can be considered as representative of most European soils, and likely be of most temperate soils worldwide; (ii) hierarchized the soil characteristics governing this variability in non-cultivated soils for different soil groups $(\mathrm{pH},<2 \mu \mathrm{m}$ fraction, cation exchange capacity (CEC), major elements) to (iii) understand how and under which pedological conditions, cultivation acts on these soil divers; and (iv) determine which soils may exhibit too low $\mathrm{Si}_{\mathrm{CaCl} 2}$ concentrations in soil solution for proper growth of wheat, a Si accumulator plant.

We implemented a spatial statistical approach based on an extensive dataset extracted from the French Soil Quality Monitoring Network database ${ }^{43}$. This dataset contains data from over 2200 sites in the France mainland, all of which were analysed for major chemical, physical, pedological, climatic, and geological parameters including $\mathrm{Si}_{\mathrm{CaCl}}$ concentrations. We focused on the $\mathrm{Si}_{\mathrm{CaCl} 2}$ soil concentrations of the surface horizons $(0-30 \mathrm{~cm})$, considered to be the horizon most explored by plant roots.

\section{Results and discussion}

Variables explaining $\mathrm{Si}_{\mathrm{CaCl} 2}$ using digital soil mapping (DSM). Concentrations of $\mathrm{Si}_{\mathrm{CaCl} 2}$ in French topsoils ranged from 2.3 to $134 \mathrm{mg} \mathrm{kg}^{-1}$ (subset 1, see Supplementary Table S1) with a 1st quartile value of $9.5 \mathrm{mg} \mathrm{kg}^{-1}$, a median of $17 \mathrm{mg} \mathrm{kg}^{-1}$, and a 3rd quartile of $28 \mathrm{mg} \mathrm{kg}^{-1}$ (Table 1). The values fell in the same range as values found elsewhere ${ }^{25,26}$.

The spatial distribution of $\mathrm{Si}_{\mathrm{CaCl} 2}$ at the French territory scale obtained by the DSM approach was evaluated by the following criteria using a 30 -fold cross validation process: $\mathrm{R}^{2}=0.43$, concordance $=0.58, \mathrm{RMSE}=13 \mathrm{mg} \mathrm{kg}^{-1}$, and bias $=0.24 \mathrm{mg} \mathrm{kg}^{-1}$. These criteria are of the same order of magnitude than those obtained in other DSM studies, at national scale, for other soil parameters, which yield $\mathrm{R}^{2}$ ranging from 0.25 to $0.55^{44-46}$. The most important covariates for predicting the spatial pattern of the $\mathrm{Si}_{\mathrm{CaCl} 2}$ concentration in the obtained Random Forest model, was, as expected, the parent material (parent_material) (Fig. 1). The second most important covariate was the so called NDVI_1, a proxy for vegetation growth dynamics as defined by Loiseau et al. ${ }^{47}$. Other important covariates for the model were soil type, precipitation, and land use, in that order. These results confirmed the data obtained in $\operatorname{Japan}^{28}$ and in Louisiana ${ }^{31}$ indicating that PAS depends on pedological/geological conditions. As a consequence, the primary spatial structures of the map (Fig. 2a) matched the parent materials and the negative correlation with total $\mathrm{Si}$ concentration ${ }^{29}$. These results also highlighted the importance of land use/vegetation on the $\mathrm{Si}_{\mathrm{CaCl} 2}$ concentration.

Physical and chemical control of $\mathrm{Si}_{\mathrm{CaCl} 2}$ in non-cultivated soils. In this part, only non-cultivated soils are considered to study the mechanisms that occur naturally in soils, without the influence of agriculture that generally strongly modifies some of the soil characteristics considered as PAS drivers, notably the soil pH by liming for slightly acidic to acidic soils, the soil organic carbon concentration (SOC). 

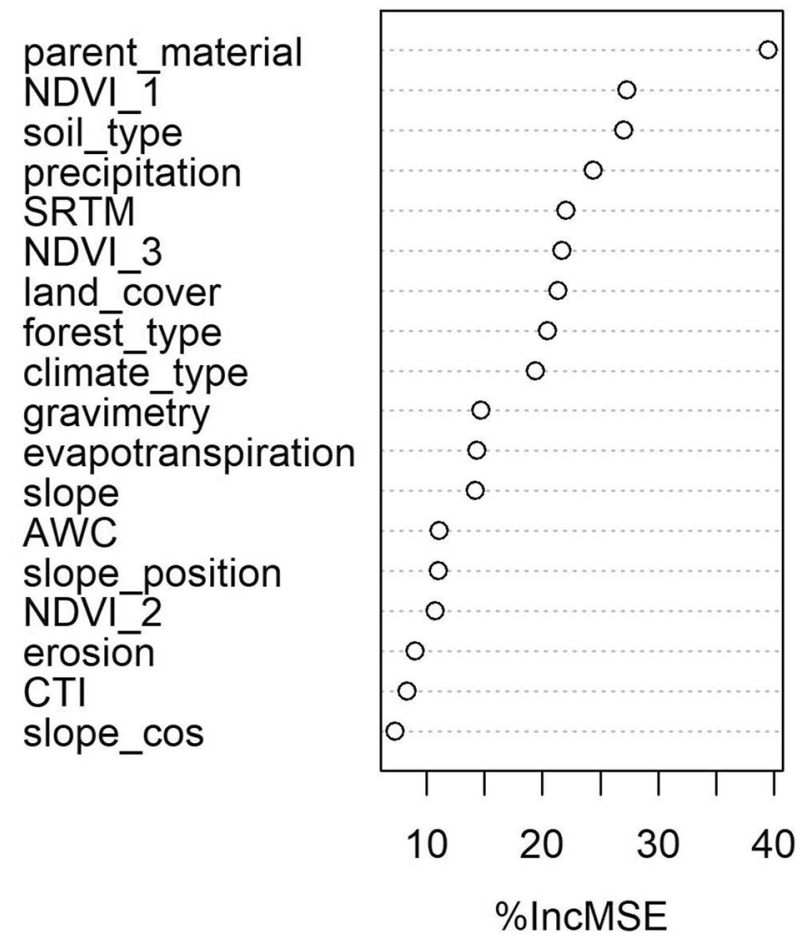

Figure 1. Importance of variables in the Random Forest model (in \% of increasing Mean Squared Error, \%IncMSE).

Overall correlations between the main soil characteristics and $S i_{C a C l 2}$ concentrations. In the non-cultivated soils, we confirmed previous findings indicating that $\mathrm{Si}_{\mathrm{CaCl} 2}$ concentration was positively correlated (Table 2) with $\mathrm{pH}$ $(\mathrm{r}=0.46)$ and the $<2 \mu \mathrm{m}$ fraction $(\mathrm{r}=0.59)$. The relationships with SOC and iron oxides (estimated by the Mehra Jackson extraction method ${ }^{48}$ ) were weaker (with $\mathrm{r}$ of 0.27 and 0.35 , respectively). $\mathrm{Si}_{\mathrm{CaCl} 2}$ was also positively correlated with CEC $(r=0.59)$, exchangeable $\mathrm{Ca}(\mathrm{r}=0.54)$, and CEC of $<2 \mu \mathrm{m}$ fraction $(\mathrm{r}=0.44)$. The correlation of $\mathrm{Si}_{\mathrm{CaCl} 2}$ with $\mathrm{pH}$ indicated that $\mathrm{Si}_{\mathrm{CaCl}}$ concentration may be controlled by $\mathrm{Si}$ adsorbed on the surface of soil minerals and/or by the soil weathering state ${ }^{25,26}$. The correlation of $\mathrm{Si}_{\mathrm{CaCl} 2}$ with the $<2 \mu \mathrm{m}$ fraction can be attributed to the presence of small phytoliths ${ }^{49}$, clay mineral dissolution ${ }^{50}$, or adsorption onto clay minerals ${ }^{51}$.

Nevertheless, while $\mathrm{Si}_{\mathrm{CaCl}}$ linearly increased with the $<2 \mu \mathrm{m}$ fraction in non-cultivated soils regardless of parent material (Fig. 3a), the correlation with $\mathrm{pH}$ was more complex. The concentration in $\mathrm{Si}_{\mathrm{CaCl} 2}$ increases with $\mathrm{pH}$ for $\mathrm{pH}$ values lower than 6-7 and then slightly decreases for $\mathrm{pH}$ larger than 8 (Fig. 3b). Such an evolution of $\mathrm{Si}_{\mathrm{CaCl}}$ with $\mathrm{pH}$ was already described in the literature ${ }^{52}$. As a consequence, there was no correlation between $\mathrm{Si}_{\mathrm{CaCl} 2}$ and the soil pH (Table 2) for carbonated soils due to their high $(>7)$ and rather constant pH values (Fig. $4 \mathrm{~b}$ ). For the SOC and Fe oxides, the relationship with $\mathrm{Si}_{\mathrm{CaCl} 2}$ is less marked, even though the $\mathrm{Si}_{\mathrm{CaCl} 2}$ concentration globally increases with these parameters (Fig. $3 \mathrm{c}$,d). As a conclusion, in non-cultivated soils, the $\mathrm{Si}_{\mathrm{CaCl} 2}$ concentration seems to be mainly driven by $<2 \mu \mathrm{m}$ content and $\mathrm{pH}$ suggesting adsorption.

The impact of $\mathrm{pH}$ on the $\mathrm{Si}_{\mathrm{CaCl} 2}$ concentration is a function of the $<2 \mu \mathrm{m}$ fraction. To explore the respective role of $\mathrm{pH}, \mathrm{CEC}$ of $<2 \mu \mathrm{m}$ fraction, and $<2 \mu \mathrm{m}$ fraction on $\mathrm{Si}_{\mathrm{CaCl}}$ concentrations in soils, we considered the correlation between soil $\mathrm{Si}_{\mathrm{CaCl}}$ concentration and soil $\mathrm{pH}$ for each of the $<2 \mu \mathrm{m}$ fractions defined in Fig. 3a. For low $<2 \mu \mathrm{m}$ fraction concentrations $\left(<50 \mathrm{~g} \mathrm{~kg}^{-1}\right)$, the $\mathrm{Si}_{\mathrm{CaCl} 2}$ concentration was significantly correlated with the $\mathrm{pH}$ but the slope of the regression was very low and appeared to be driven by a few extreme values (Fig. 5). As a result, $\mathrm{Si}_{\mathrm{CaCl}}$ concentrations increased minimally from $3.3-4.3 \mathrm{mg} \mathrm{kg}^{-1}$ to $6.4-9.3 \mathrm{mg} \mathrm{kg}^{-1}$ in $4.5 \mathrm{pH}$ units, demonstrating the low impact of $\mathrm{pH}$ on $\mathrm{Si}_{\mathrm{CaCl} 2}$ concentration for soils with poor $<2 \mu \mathrm{m}$ fractions. For $<2 \mu \mathrm{m}$ fraction concentrations ranging from 50 to $325 \mathrm{~g} \mathrm{~kg}^{-1}, \mathrm{Si}_{\mathrm{CaCl} 2}$ concentration increased with $\mathrm{pH}$. Nevertheless, for $<2 \mu \mathrm{m}$ fraction content higher than $230 \mathrm{~g} \mathrm{~kg}^{-1}$, the increase of $\mathrm{Si}_{\mathrm{CaCl} 2}$ with $\mathrm{pH}$ is smaller. No correlation is observed for $<2 \mu \mathrm{m}$ fraction concentrations higher than $325 \mathrm{~g} \mathrm{~kg}^{-1}$, indicating that adsorption might not be the dominant process at these $<2 \mu \mathrm{m}$ contents. Carbonated soils are in this $<2 \mu \mathrm{m}$ fraction range (median of $364 \mathrm{~g} \mathrm{~kg}^{-1}$, Supplementary Table S2) explaining the absence of correlation of $\mathrm{Si}_{\mathrm{CaCl} 2}$ with $\mathrm{pH}$.

As a conclusion, the classically described increase of $\mathrm{Si}_{\mathrm{CaCl} 2}$ with $\mathrm{pH}$ (explained by $\mathrm{Si}$ adsorption processes) was only encountered in temperate soils for non-carbonated soils with $<2 \mu \mathrm{m}$ concentrations higher than $50 \mathrm{~g} \mathrm{~kg}^{-1}$ or lower than $325 \mathrm{~g} \mathrm{~kg}^{-1}$.

Impact of the nature of the $<2 \mu \mathrm{m}$ fraction on $\mathrm{Si}_{\mathrm{CaCl} 2}$ concentration. The $<2 \mu \mathrm{m}$ CEC can be used as a proxy for the nature of the clay minerals of the soil as shown by the contrasted CEC of the different clay minerals provided by Goldberg et al. ${ }^{53}$. On this basis ${ }^{53}$, we assumed that (i) soils with $<2 \mu \mathrm{m} \mathrm{CEC} \mathrm{lower} \mathrm{than} 10 \mathrm{cmol}^{+} \mathrm{kg}^{-1}$ were 

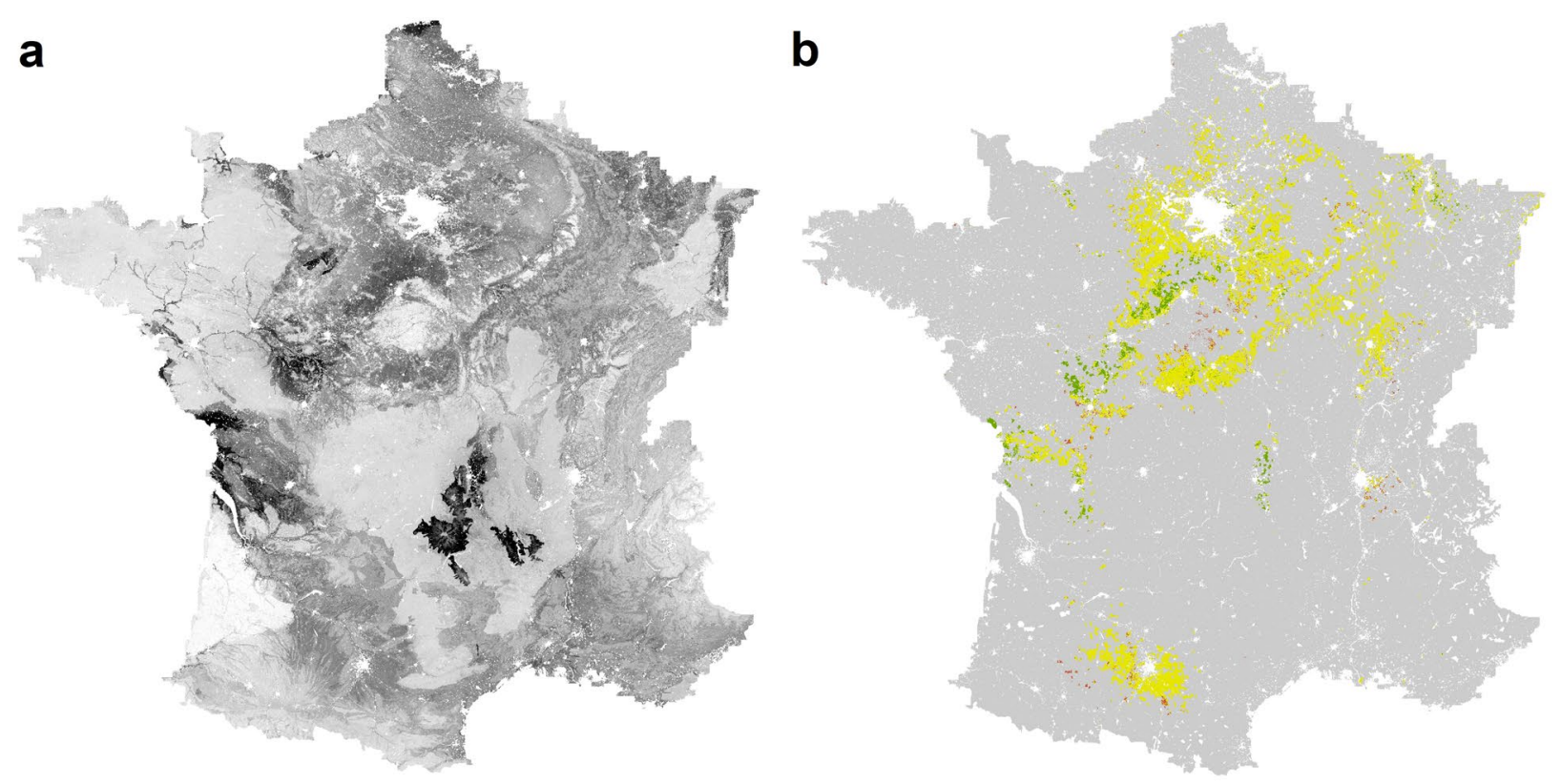

\section{$\mathrm{Si}_{\mathrm{CaCl2}}\left(\mathrm{mg} \mathrm{kg}^{-1}\right)$}

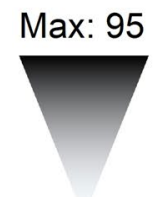

Min : 2.0

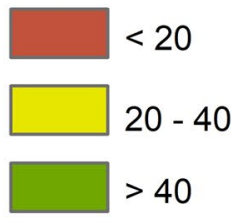

Mask of non cultivated land + non principal wheat-producing regions

Figure 2. Regression Kriging predictions of $\mathrm{Si}_{\mathrm{CaCl}}$ concentrations in French topsoils at $90 \mathrm{~m}$ resolution. (a) continuous colour gradient representation; (b) categorical representation in 3 classes of $\mathrm{Si}_{\mathrm{CaCl} 2}$ concentrations based on critical values defined for sugarcane and rice ${ }^{28,29,31}$ for soils cropped in wheat, obtained by crossing the 'arable land' pixels, 'permanent crop' and 'heterogeneous agricultural' areas with the exception of 'agroforestry' of Corine Land Cover classes ${ }^{54}$ with municipalities for which type of farming is primarily cereal crop, according to French OTEX classification (Orientation Technico-Economique des Exploitations). We removed the municipalities from 7 departments (Ain, Haut-Rhin, Bas-Rhin, Gironde, Pyrénées-Atlantiques, Hautes Pyrénées, Landes) where corn is the main cereal under production. Maps were generated using ArcGIS software version 10.7.1 (ESRI: https://www.esri.com/en-us/home).

\begin{tabular}{|l|l|l|l|r|}
\hline Class & $\mathrm{Si}_{\mathrm{CaCl} 2} \sim \mathbf{p H}$ & $\mathrm{Si}_{\mathrm{CaCl} 2} \sim(<2 \mu \mathrm{m}$ fraction $)$ & $\mathrm{Si}_{\mathrm{CaCl} 2} \sim(<2 \mu \mathrm{m}$ CEC $)$ & $\mathbf{n}$ \\
\hline All non-cultivated soils & $\mathbf{0 . 4 6}$ & $\mathbf{0 . 5 9}$ & $\mathbf{0 . 4 4}$ & 1065 \\
\hline Carbonated soils on sediment & -0.099 & $\mathbf{0 . 2}$ & 0.093 & 219 \\
\hline Soils on igneous extrusive rock & $\mathbf{0 . 6 3}$ & $\mathbf{0 . 6 6}$ & $\mathbf{0 . 6 3}$ & 27 \\
\hline Soils on igneous intrusive rock & $\mathbf{0 . 2 5}$ & $\mathbf{0 . 3 9}$ & $\mathbf{0 . 3 6}$ & 109 \\
\hline Soils on metamorphic rock & $\mathbf{0 . 3}$ & $\mathbf{0 . 4 2}$ & $\mathbf{0 . 3}$ & 120 \\
\hline Non-carbonated soils on sediment & $\mathbf{0 . 4 8}$ & $\mathbf{0 . 6 8}$ & $\mathbf{0 . 4 8}$ & 537 \\
\hline Podzols & 0.034 & $\mathbf{0 . 8 1}$ & 0.15 & 53 \\
\hline
\end{tabular}

Table 2. Correlation coefficients between $\mathrm{Si}_{\mathrm{CaCl} 2}$ and $\mathrm{pH},<2 \mu \mathrm{m}$, and CEC of the $<2 \mu \mathrm{m}$ fraction $(<2 \mu \mathrm{m}$ $\mathrm{CEC}$ ) for the non-agricultural soils as a whole and by classes of parent material. Significant correlations (p value $<0.05)$ are reported in bold. Medians sharing a letter are not significantly different according to pairwise comparisons of Wilcoxon test with Tukey adjustment for multiple comparisons.

primarily kaolinitic or possessed $\mathrm{a}<2 \mu \mathrm{m}$ fraction rich in quartz; (ii) soils with $<2 \mu \mathrm{m}$ CEC ranging from 10 to $40 \mathrm{cmol}^{+} \mathrm{kg}^{-1}$ contained a large amount of illite and chlorite or a complex mixture of clay minerals; and (iii) soils with $\mathrm{a}<2 \mu \mathrm{m}$ CEC larger than $40 \mathrm{cmol}^{+} \mathrm{kg}^{-1}$ contained a large quantity of vermiculite and smectite.

A correlation of the $\mathrm{Si}_{\mathrm{CaCl} 2}$ concentrations with the $<2 \mu \mathrm{m}$ CEC (a proxy for the nature of the clay minerals of the soil) was observed globally and for all non-carbonated parent material, with the exception of podzols (Table 2), suggesting a role of the nature of the clay minerals on the $\mathrm{Si}_{\mathrm{CaCl} 2}$ concentrations. However, Fig. 5 

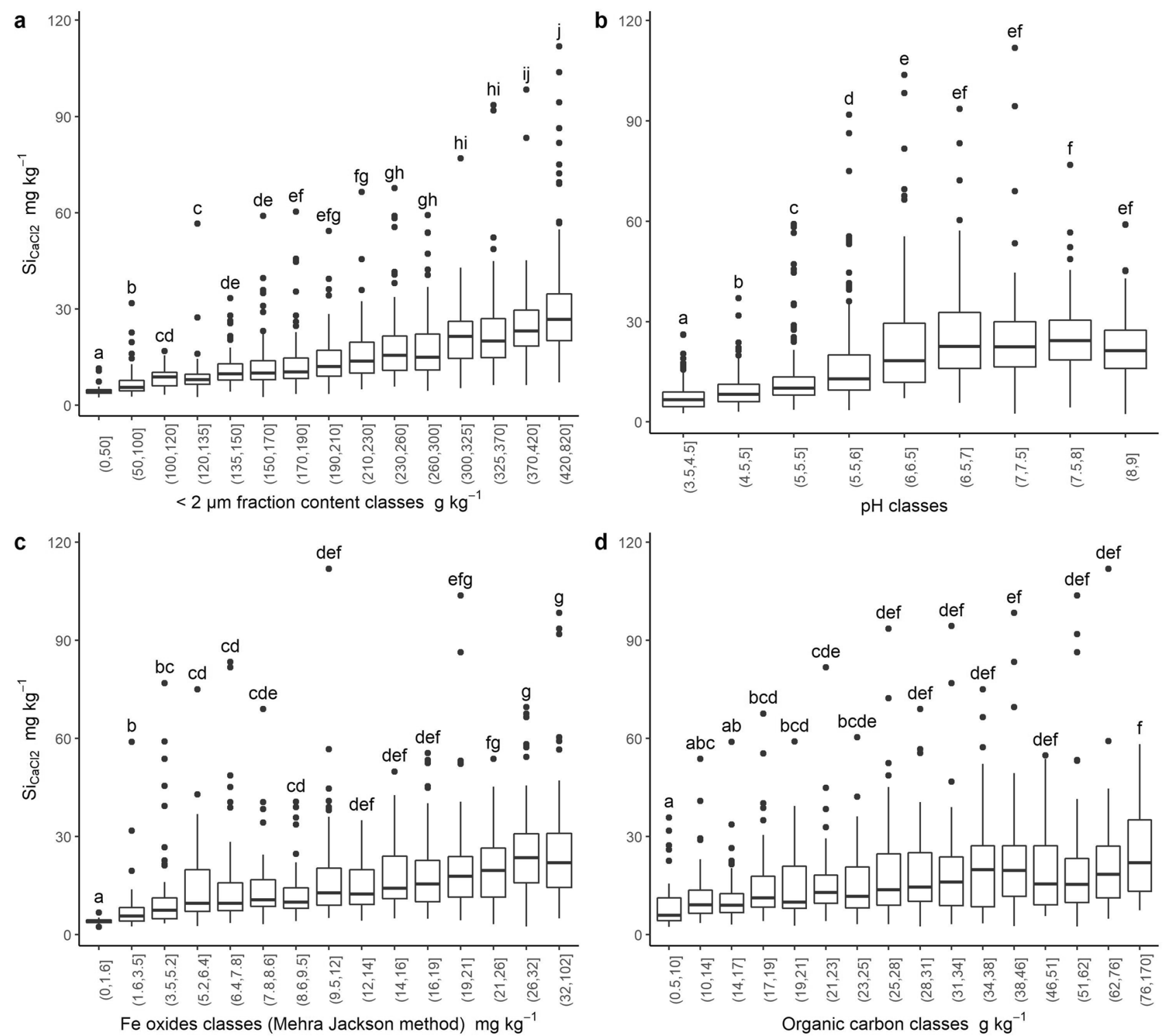

Figure 3. Boxplots of $\mathrm{Si}_{\mathrm{CaCl} 2}$ concentration as a function of $(\mathbf{a})<2 \mu \mathrm{m}$ fraction content classes, (b) $\mathrm{pH}$ classes, (c) Fe oxides concentration (estimated by the Mehra Jackson method) classes (d) soil organic carbon content classes for non-cultivated soils only. Classes have been created so that uncertainty around the central value does not overlap with the uncertainty around the central value of the surrounding classes. Classes with less than 40 individuals were merged. Groups of individuals sharing a letter are not significantly different according to pairwise comparisons of Wilcoxon test with Tukey adjustment for multiple comparisons.

shows that soil $\mathrm{pH}$ and clay nature were linked, with acidic soils being mainly kaolinitic and basic soils being more smectitic or rich in vermiculite. This could partially explain the link between $\mathrm{Si}_{\mathrm{CaCl}}$ concentration and $\mathrm{pH}$, because kaolinites are more stable than other clay minerals (e.g. smectite) ${ }^{14}$.

For carbonated soils developed on sedimentary parent materials and podzols, the $\mathrm{Si}_{\mathrm{CaCl} 2}$ concentrations did not appear to be impacted by the nature of the corresponding clay mineral ( $<2 \mu \mathrm{m}$ CEC) (Table 2$)$. In carbonated soils on sediment parent material, the clay mineral assemblage was primarily dominated by smectite and vermiculite, according to the $<2 \mu \mathrm{m}$ CEC recorded (Fig. $4 \mathrm{~d}$ ). In podzols, the nature of the clay minerals did not vary much and primarily consisted of kaolinite and quartz in the $<2 \mu \mathrm{m}$ fraction (see the very low $<2 \mu \mathrm{m}$ CEC in Supplementary Table S2).

Our results showed that the increase in $\mathrm{Si}_{\mathrm{CaCl}}$ concentrations in tandem with $\mathrm{pH}$ may be explained by changes in the nature of the underlying mineralogy of the $<2 \mu \mathrm{m}$ fraction. In acidic soils with kaolinite as the primary clay component, the $\mathrm{Si}_{\mathrm{CaCl}}$ was lower than in soils with a near neutral $\mathrm{pH}$, with a primary clay component of smectite.

Impact of agriculture on available silicon in soils. For soils derived from carbonated and non-carbonated sediment material ( $73 \%$ of French soils), $\mathrm{Si}_{\mathrm{CaCl} 2}$ significantly increased in the cultivated soils (perennial and annual crop) as compared to soils at uncultivated sites (Fig. 4a). Indeed, the results of linear model showed that 
a

non-cult. cult. non-cult. cult. non-cult. cult. non-cult. cult.

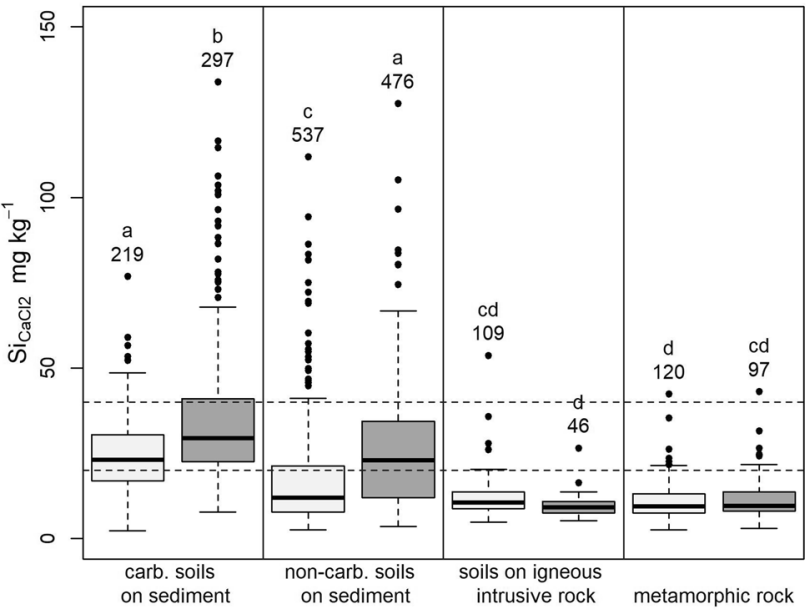

C

non-cult. cult. non-cult. cult. non-cult. cult. non-cult. cult.

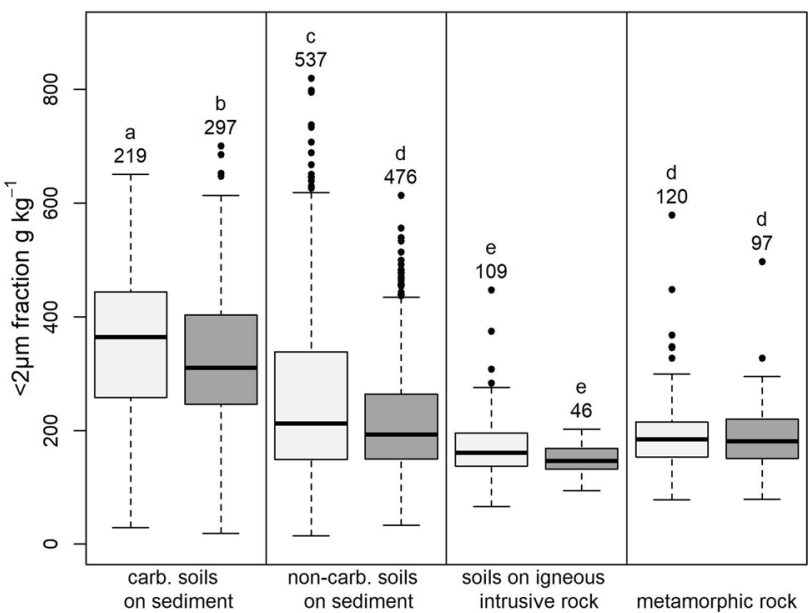

b

non-cult. cult. non-cult. cult. non-cult. cult. non-cult. cult.

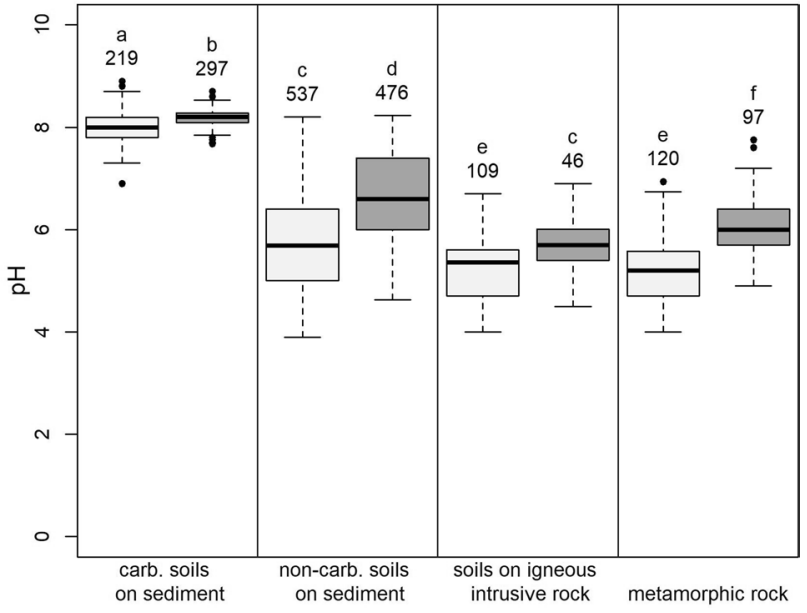

d

non-cult. cult. non-cult. cult. non-cult. cult. non-cult. cult.

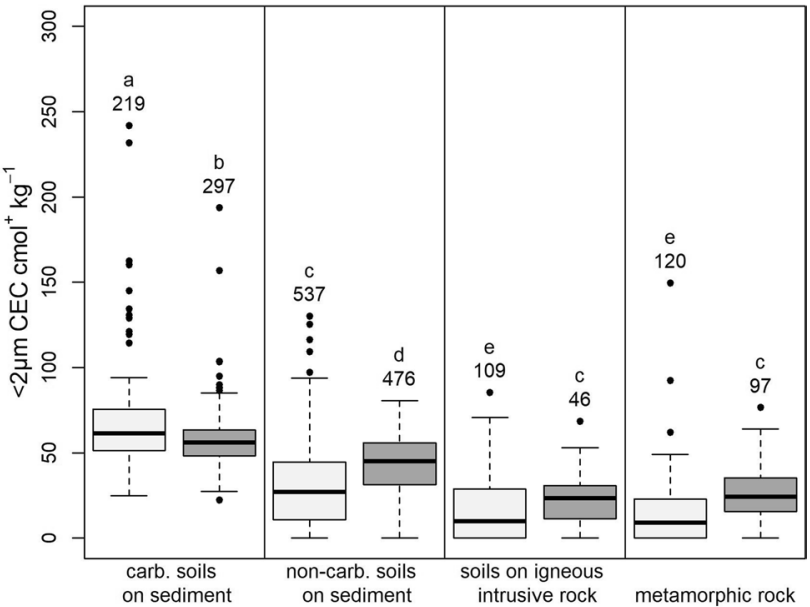

Figure 4. Boxplots by parent materials and land uses of: (a) $\mathrm{Si}_{\mathrm{CaCl} 2}$, (b) soil $\mathrm{pH}$, (c) $<2 \mu \mathrm{m}$ fraction content, and $(\mathbf{d})<2 \mu \mathrm{m}$ CEC. Groups of individuals sharing a letter are not significantly different according to pairwise comparisons of Wilcoxon test with Tukey adjustment for multiple comparisons.

about $12 \%$ of the total variance is explained by this difference. However, for soils derived from igneous intrusive rock and metamorphic rock, there was no significant difference in $\mathrm{Si}_{\mathrm{CaCl}}$ concentrations between cultivated and non-cultivated sites. For these two parent materials, $\mathrm{Si}_{\mathrm{CaCl} 2}$ concentrations were very low, as compared to other parent materials. Thus contrarily to what was expected, cultivation increases $\mathrm{Si}_{\mathrm{CaCl} 2}$ concentrations but only in soils where this concentration is not too low.

Cultivated soils exhibited significantly higher $\mathrm{pH}$ values than uncultivated vegetated soils, regardless of parent material (Fig. 4b) due to liming practices on cultivation, with the notable exception of the carbonated soils, which are generally not limed. For carbonated soils, the difference of $\mathrm{pH}$ was due to acidifying conditions under noncultivation, as compared to agricultural conditions. The difference in $\mathrm{pH}$ between cultivated and non-cultivated soils was less than 0.5 for carbonated soils on sediment and igneous intrusive rocks. Since carbonated soils have $\mathrm{a}<2 \mu \mathrm{m}$ fraction content higher than $325 \mathrm{~g} \mathrm{~kg}^{-1}, \mathrm{pH}$ has no effect on the $\mathrm{Si}_{\mathrm{CaCl}}$ concentration as shown by Fig. 5 and Table 2.

For non-carbonated soils on sediments and soils on metamorphic rocks, the difference was higher: the average $\mathrm{pH}$ of non-cultivated soils was 5.7 and 5.2, while the average $\mathrm{pH}$ of cultivated soils was 6.7 and 6.1 respectively for non-carbonated soils on sediments and metamorphic rocks (Supplementary Table S2).

As shown in Fig. 4c (and Supplementary Table S2), the $<2 \mu \mathrm{m}$ fractions for non-carbonated soils on sediments primarily comprised 50 to $325 \mathrm{~g} \mathrm{~kg}^{-1}$. For this $<2 \mu \mathrm{m}$ fraction range, we showed that the $\mathrm{Si}_{\mathrm{CaCl} 2}$ concentration increased with $\mathrm{pH}$ (Fig. 5). Therefore, cultivation associated to a $\mathrm{pH}$ increase by liming may be responsible for the $\mathrm{Si}_{\mathrm{CaCl} 2}$ concentration increase under cultivation for these soils. This $\mathrm{pH}$ increase was also associated with an increase in $<2 \mu \mathrm{m}$ CEC and therefore with a higher smectite/vermiculite content under cultivation, and a higher illite/chorite content under permanent vegetation (Fig. 4d). Similar changes in clay mineral composition following changes in land use were observed on paired site approaches (Cornu et al. ${ }^{54}$ and references herein). 


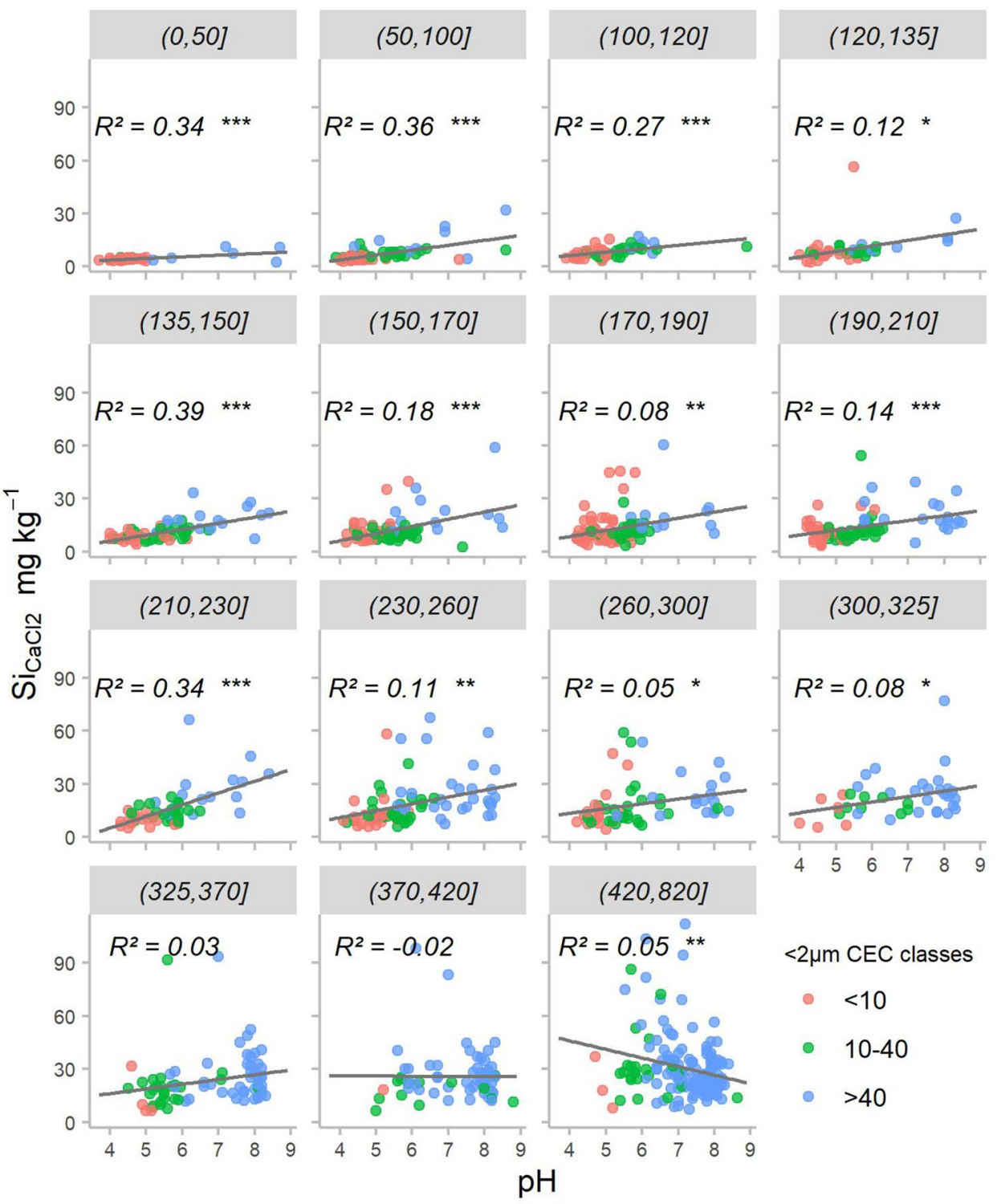

Figure 5. Relationship between topsoil $\mathrm{Si}_{\mathrm{CaCl} 2}$ and $\mathrm{pH}$ for the different $<2 \mu \mathrm{m}$ content classes defined in Fig. 3 , for non-cultivated soils. The classes of $<2 \mu \mathrm{m}$ contents are expressed in $\mathrm{g} \mathrm{kg}^{-1}$ and reported in the grey box at the top of the corresponding graph. The colours identify the classes of $<2 \mu \mathrm{m}$ CEC corresponding to the classes of clay mineral CEC values provided by Goldberg et al..$^{53}$. Observations with $<2 \mu \mathrm{m}$ CEC values larger than $100 \mathrm{cmol}^{+} \mathrm{kg}^{-1}$ were eliminated (20 observations). Associated $\mathrm{R}^{2}$ values and levels of significance are

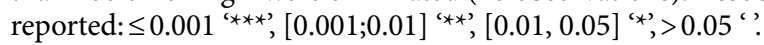

The $\mathrm{pH}$-driven effects of liming on $\mathrm{Si}_{\mathrm{CaCl} 2}$ concentrations have already been observed ${ }^{52}$. Indeed, increases in $\mathrm{pH}$ could cause higher adsorption of silicon to soil minerals and facilitate the solubilization of phytoliths in the soil solution, thus increasing the $\mathrm{Si}_{\mathrm{CaCl} 2}$ concentration at short time scales ${ }^{52}$.

Consequences in terms of potential PAS deficiency for wheat in temperate soils. To our knowledge, no study has defined the critical level of $\mathrm{Si}_{\mathrm{CaCl}}$ for avoiding $\mathrm{Si}$ deficiency for temperate staple crops as wheat. Critical levels are, however, available in the literature for rice and sugarcane; these levels are adopted as references for discussion here because wheat has a shoot Si concentration between those of rice and sugarcane ${ }^{10}$. We proposed two critical values: a lower bound $\left(20 \mathrm{mg} \mathrm{kg}^{-1}\right)$ defined by Haysom and Chapman ${ }^{33}$ for sugarcane in Australia, and an upper bound $\left(40 \mathrm{mg} \mathrm{kg}^{-1}\right)$, an average value provided for rice based on data from silt loam in Louisiana soils ${ }^{31}$ (37 and $43 \mathrm{mg} \mathrm{kg}{ }^{-1}$ ) and from southern acidic soils in India ${ }^{30}\left(43 \mathrm{mg} \mathrm{kg}{ }^{-1}\right)$. We applied these two thresholds to the French soils cultivated with wheat, obtained by crossing the arable land pixels defined to Corine Land Cover map ${ }^{55}$ with the cereal producing municipalities from the French OTEX classification (the Technico-economic orientation of the farms, http://agreste.agriculture.gouv.fr), to quantify the importance of potential $\mathrm{Si}_{\mathrm{CaCl} 2}$ deficiency in temperate soils (Fig. $2 \mathrm{~b}$ ). It results that only $4 \%$ of the soils cultivated with wheat fell below the $20 \mathrm{mg} \mathrm{kg}^{-1}$ critical level and could therefore be depleted of plant available Si. However, this hypoth- 
esis requires a more technical definition of the Si requirements of wheat. Indeed, this would enable to determine if the soils having concentrations between 20 and $40 \mathrm{mg} \mathrm{kg}^{-1}$ and representing $85 \%$ of the surfaces cultivated with wheat are below or under the critical level for wheat.

\section{Materials and methods}

Soil data from RMQS program. The soil data used in this study were provided by the French Soil Quality Monitoring Network (RMQS). The RMQS network consists of observation sites situated at the centre of a regular grid $\left(16^{*} 16 \mathrm{~km}\right)$ covering the French territory. It provides 2111 sites in metropolitan France, almost half of which are cultivated (permanent crops or field crops) and the remaining of which consist of pastures, natural vegetation, or urban soils. The dataset used in this study corresponds to the first sampling campaign of the RMQS carried out from 2000 to 2009.

Soil type, parent material, climate, and land use were described in the field. At each site, 25 core samples were taken within a $20 \mathrm{~m} \times 20 \mathrm{~m}$ plot and combined into a composite sample. Sampling depth generally consisted of the $0-30 \mathrm{~cm}_{\text {layer }}{ }^{43}$. The composite samples were air-dried and sieved to $2 \mathrm{~mm}$ before being analysed in Soil Analysis Laboratory of INRAE (Arras, France).

The following parameters were measured: (i) the total soil organic carbon concentration, as measured by dry combustion (NF ISO 10694); (ii) the particle size distribution, by wet sieving and pipette method (NF X 31-107); (iii) cation exchange capacity (CEC) and exchangeable cations (cobaltihexamin method, NF X 31-130); (iv) $\mathrm{pH}$ in water ( 1 to 5 soil to water ratio, NF X 31-107); (v) calcium carbonate, using the volumetric method (NF X 31-106) $\left(\mathrm{CaCO}_{3}\right)$; and (vi) total $\mathrm{P}, \mathrm{K}, \mathrm{Ca}, \mathrm{Mg}, \mathrm{Fe}$, and $\mathrm{Al}$, determined by ICP-MS after dissolution with hydrofluoric and perchloric acids (NF X 31-147). The $<2 \mu \mathrm{m}$ CEC was estimated as follows:

$$
2 \mu \mathrm{m} C E C=\frac{(C E C-0.15 * O C)}{<2 \mu \mathrm{m} \text { fraction content }} * 1000
$$

with CEC in $\mathrm{cmol}^{+} \mathrm{kg}^{-1}$, OC in $\mathrm{g} \mathrm{kg}^{-1}$, and $<2 \mu \mathrm{m}$ faction content in $\mathrm{g} \mathrm{kg}^{-1}$. We used $0.15 \mathrm{cmol}^{+} \mathrm{kg}^{-1}$ as an estimate of the CEC of organic matter.

Total Si was analysed from a subset of 673 samples by ICP after alkaline fusion ${ }^{56}$, and extrapolated to the remaining sites using the following conceptual equation:

$$
\mathrm{Si}=f\left(\mathrm{Al}, \mathrm{Fe}, \mathrm{K}, \mathrm{Na}, \mathrm{Ca}_{n c}, \mathrm{Mg}_{n c}, \mathrm{P}, \mathrm{SOC}, \mathrm{CaCo}_{3} \text {, residual water }\right)
$$

where $C a_{n c}$ and $M g_{n c}$ are the fractions of $\mathrm{Ca}$ and $\mathrm{Mg}$, respectively, that are not included in carbonate minerals or adsorbed to the exchangeable surfaces, and SOC is the organic carbon percentage. This model was implemented in cubis $\mathrm{t}^{29}$ and yielded an $\mathrm{R}^{2}$ value greater than 0.98 .

Bioavailable $\mathrm{Si}\left(\mathrm{Si}_{\mathrm{CaCl}}\right)$ was estimated on samples from 2091 sites using the $0.01 \mathrm{M} \mathrm{CaCl}_{2} \operatorname{method}^{33}$. This widely adopted method ${ }^{25}$ allows estimation of the pool of readily soluble $\mathrm{Si}$.

Bulk samples were equilibrated during $16 \mathrm{~h}$ at room temperature with $0.01 \mathrm{M} \mathrm{CaCl}_{2}$ with a solid:liquid ratio of 1:10. Si was then analyzed, after filtration of the supernatant at $0.45 \mu \mathrm{m}$, by Inductively Coupled Plasma Atomic Emission Spectroscopy (axial ICP-AES; 720 ES, Varian) ${ }^{29}$. The limit of quantification of the method was of $0.5 \mathrm{mg} \mathrm{kg}^{-1}$ with an uncertainty, $\mathrm{U}$, (with a confidence level of 0.95 ) evaluated as follow:

$$
U=0.0271 * \mathrm{Si}_{\mathrm{CaCl} 2}+0.25
$$

with $\mathrm{Si}_{\mathrm{CaCl} 2}$ and $\mathrm{U}$ expressed in $\mathrm{mg} \mathrm{kg}^{-1}$.

To decipher the impact of agricultural use on $\mathrm{Si}_{\mathrm{CaCl} 2}$ concentration, we stratified the database by (i) parent material, based on the European Soil Information System (EUSIS) classification ${ }^{57}$ available at the French territory scale as in Landré et al. ${ }^{29}$; and by (ii) land use. The group of soils developed on sediment was cut into two subgroups (carbonated and non-carbonated depending on their carbonate content $(>1 \%$ and $<1 \%$ respectively). We considered soils under forests, pastures, parks, natural vegetation, and wetlands to be non-cultivated soils. We did not make any distinction of land use for soils on igneous extrusive rocks (volcanic) and podzols, because cultivation of these soil types was limited to two and three sites, respectively.

Our statistical analysis was based on a subset of 1986 data points (subset 1, see Supplementary Table S1) due to the removal from the initial 2091 point dataset of any sites with missing geological information and three sites with peat soils.

Digital soil mapping approach. To map and define the spatial distribution of $\mathrm{Si}_{\mathrm{CaCl} 2}$ concentrations, we implemented a digital soil mapping (DSM) approach based on the scorpan model framework proposed by McBratney et al. ${ }^{58}$, a spatial prediction function utilizing quantitative relationships between soil properties and soil forming factors as follows:

$$
\text { Soil }_{x}=f(s, c, o, r, p, a, n)+e
$$

where Soil is a soil property at position $x$. The $s$ refers to soil information derived from prior soil maps or from remote or proximal sensing data; $c$ refers to the climatic properties of the environment at a given point; $o$ refers to organisms, including vegetation, fauna, or human activity; $r$ refers to relief; $p$ refers to the parent material or lithology; $a$ refers to the soil age; $n$ refers to space or spatial position; and $e$ is the spatially correlated errors.

To apply this model, we retained a set of spatial covariates describing scorpan factors to predict the spatial distribution of $\mathrm{Si}_{\mathrm{CaCl}}$ at $90 \mathrm{~m}$ resolution. All covariates were previously resampled at the same resolution. The selection was carried out from a larger set of covariates using a combination of expert knowledge and statistical 
approaches. The latter was based on the boruta package in $\mathrm{R}^{59}$. This algorithm uses the classification of the covariate importance implemented in the randomForest package and compares the importance with random variables based on the $\mathrm{Z}$ score value. This step allows the identification of the most relevant covariates before fitting a prediction model. The initial 18 spatial covariates represented the scorpan factors as follows: soil (map of soil type and available water capacity (AWC)), climate (map of climate type, precipitation, and evapotranspiration), vegetation (land use, forest type), parent material (parent material types and gravimetry), and relief (shuttle radar topography mission (SRTM), compound topographic index (CTI), slope cosine, erosion, slope, and slope position). A final covariate corresponding to the normalized difference vegetation index (NDVI) was derived from remote sensing data. This spectral index is widely used to describe the photosynthetic capacity of vegetative cover. The underlying assumption driving this method holds that changes in vegetation may reflect various plant responses to climate, land management, or soil properties ${ }^{47}$. This covariate was computed from a large time series dataset. To summarise the temporal data, Loiseau et al. ${ }^{47}$ performed a principal component analysis that yielded 3 covariates corresponding to the 3 first components: NDVI_1, NDVI_2, and NDVI_3.

For the scorpan model, we developed a regression kriging (RK) model using the selected covariates and soil observations. The RK model is a hybrid technique combining a Random Forest approach with a geostatistical approach. Random Forest ${ }^{60}$ consists of an ensemble of regression trees built from covariates and point data. The final prediction is the mean of the individual tree predictions. This technique is applicable in $\mathrm{R}$ and requires two main parameters: the number of randomly selected splitting variables at each tree (mtry), and the number of trees (ntree). We used the default parameters provided by the package (mtry $=6$ and ntree $=500$ ). The final predictions are the sum of the Random Forest predictions and the residuals computed through an ordinary kriging procedure ${ }^{61}$.

The RK model was fitted on the on a subset of the RMQS sites for which covariate information were available (subset 2: 1987 points, see Supplementary Table S1). This procedure was implemented with the package GSIF', which also allows fitting of residuals in a variogram.

To assess the covariates importance in the model, we used the function varImp() implemented in the Random Forest package. The function calculates the difference in MSE (Mean Squared Error) when the values of each predictor are shuffled. This indicator is then normalized by the standard deviation of the differences to obtain the Increase in MSE noted \%IncMSE. The highest values are attributed to the more important variables.

The validity of the fitted prediction model was evaluated by a 30 -fold cross validation. At each step, the soil dataset was split into two datasets: $2 / 3$ for calibration, and $1 / 3$ for validation.

To obtain an estimate of the final map accuracy, the validation indicators were calculated at each iteration and then averaged over the 30 repetitions. We used different indicators for validation, including the Root Mean Square Error (RMSE), the coefficient of determination $\left(\mathrm{R}^{2}\right)$, the concordance $\mathrm{e}^{63}$, and the bias.

Take home messages. The $\mathrm{Si}_{\mathrm{CaCl} 2}$ concentrations in French soils is highly variable (from 2.3 to $134 \mathrm{mg} \mathrm{kg}^{-1}$ ) and depends mainly on parent material and soil type, but also on the land use.

When the soils are cultivated, the concentration in $\mathrm{Si}_{\mathrm{CaCl} 2}$ significantly increases for soils developed on sediment parent material but not for those developed on metamorphic rocks and igneous intrusive rocks. For these two last parent materials, $\mathrm{Si}_{\mathrm{CaCl}}$ concentration is low compared to soils developed on sediments. For soil developed on igneous extrusive rocks and podzol, no conclusion on the impact of agriculture on $\mathrm{Si}_{\mathrm{CaCl} 2}$ concentrations could be drawn due to the low number of sites under cultivation for these soils in France. For non-carbonated soils, this increase is due to the $\mathrm{pH}$ increase associated to liming practices. More research is needed to better understand the impact of cultivation on $\mathrm{Si}_{\mathrm{CaCl} 2}$ concentration for carbonated soils for example through a paired sites approach.

We also verified on this large panel of temperate soils that the $\mathrm{Si}_{\mathrm{CaCl} 2}$ concentration is governed by the $<2 \mu \mathrm{m}$ fraction, $\mathrm{pH}$, and iron oxide content to a lesser extent. The nature of the clay assemblage seemed also to act on the $\mathrm{Si}_{\mathrm{CaCl} 2}$ concentration. We however showed that the $\mathrm{Si}_{\mathrm{CaCl} 2}$ concentration increases with $\mathrm{pH}$ only for soils with content in $<2 \mu \mathrm{m}$ fraction ranging from 50 to $325 \mathrm{~g} \mathrm{~kg}^{-1}$.

We also showed that $4 \%$ of the soils cropped with wheat could be deficient in $\mathrm{Si}_{\mathrm{CaCl}}$. This result was based on critical level of $\mathrm{Si}_{\mathrm{CaCl} 2}$ estimated for sugar cane and rice. Studies should be done to determine precisely the critical level for wheat.

At last, this study did not allow accessing the kinetic aspects. Other Si pools and/or chronosequences studies should be analyzed to answer this question.

\section{Data availability}

The dataset analysed during the current study can be retrieved from https://doi.org/10.15454/CFWBAA ${ }^{64}$. However, the location information is not publicly accessible because the data contain confidential information.

Received: 6 April 2020; Accepted: 15 October 2020

Published online: 17 November 2020

\section{References}

1. Coskun, D. et al. The controversies of silicon's role in plant biology. New Phytol. 221, 67-85 (2019).

2. Datnoff, L. E., Snyder, G. H. \& Korndörfer, G. H. Silicon in Agriculture (Elsevier, Amsterdam, 2001).

3. Epstein, E. The anomaly of silicon in plant biology. Proc. Natl. Acad. Sci. 91, 11-17 (1994).

4. Liang, Y., Sun, W., Zhu, Y.-G. \& Christie, P. Mechanisms of silicon-mediated alleviation of abiotic stresses in higher plants: A review. Environ. Pollut. 147, 422-428 (2007).

5. Meunier, J. D. et al. Effect of phytoliths for mitigating water stress in durum wheat. New Phytol. 215, 229-239 (2017).

6. Exley, C. \& Guerriero, G. A reappraisal of biological silicification in plants?. New Phytol. 223, 511-513 (2019). 
7. Liang, Y., Nikolic, M., Bélanger, R., Gong, H. \& Song, A. Silicon in Agriculture (Springer, Dordrecht, 2015). https://doi. org/10.1007/978-94-017-9978-2.

8. Guntzer, F., Keller, C. \& Meunier, J.-D. Benefits of plant silicon for crops: A review. Agron. Sustain. Dev. 32, 201-213 (2012).

9. Katz, O. Silica phytoliths in angiosperms: Phylogeny and early evolutionary history. New Phytol. 208, 642-646 (2015).

10. Hodson, M. J., White, P. J., Mead, A. \& Broadley, M. R. Phylogenetic variation in the silicon composition of plants. Ann. Bot. 96, 1027-1046 (2005).

11. Darmawan, et al. Effect of long-term intensive rice cultivation on the available silica content of sawah soils: Java Island, Indonesia. Soil Sci. Plant Nutr. 52, 745-753 (2006).

12. Savant, N. K., Datnoff, L. E. \& Snyder, G. H. Depletion of plant-available silicon in soils: A possible cause of declining rice yields. Commun. Soil Sci. Plant Anal. 28, 1245-1252 (1997).

13. Yan, G., Nikolic, M., Ye, M., Xiao, Z. \& Liang, Y. Silicon acquisition and accumulation in plant and its significance for agriculture. J. Integr. Agric. 17, 2138-2150 (2018).

14. Cornelis, J.-T. \& Delvaux, B. Soil processes drive the biological silicon feedback loop. Funct. Ecol. 30, 1298-1310 (2016).

15. Alexandre, A., Meunier, J.-D., Colin, F. \& Koud, J.-M. Plant impact on the biogeochemical cycle of silicon and related weathering processes. Geochim. Cosmochim. Acta 61, 677-682 (1997).

16. Derry, L. A., Kurtz, A. C., Ziegler, K. \& Chadwick, O. A. Biological control of terrestrial silica cycling and export fluxes to watersheds. Nature 433, 728-731 (2005).

17. Berner, E. K. \& Berner, R. A. Global Environment: Water, Air and Geochemical Cycles (Prentice Hall, Old Tappan, 1996).

18. Brantley, S. L. Reaction kinetics of primary rock-forming minerals under ambient conditions. In Treatise on Geochemistry, Vol. 5 (Elsevier, Amsterdam, 2005).

19. Riotte, J. et al. Processes controlling silicon isotopic fractionation in a forested tropical watershed: Mule Hole Critical Zone Observatory (Southern India). Geochim. Cosmochim. Acta 228, 301-319 (2018).

20. Puppe, D., Kaczorek, D., Wanner, M. \& Sommer, M. Dynamics and drivers of the protozoic Si pool along a 10-year chronosequence of initial ecosystem states. Ecol. Eng. 70, 477-482 (2014).

21. Hiemstra, T., Barnett, M. O. \& van Riemsdijk, W. H. Interaction of silicic acid with goethite. J Colloid Interface Sci 310, 8-17 (2007).

22. Sauer, D., Saccone, L., Conley, D. J., Herrmann, L. \& Sommer, M. Review of methodologies for extracting plant-available and amorphous Si from soils and aquatic sediments. Biogeochemistry 80, 89-108 (2006).

23. Tubaña, B. S. \& Heckman, J. R. Silicon in soils and plants. In Silicon and Plant Diseases (eds Rodrigues, F. A. \& Datnoff, L. E.) (Springer International Publishing, Berlin, 2015). https://doi.org/10.1007/978-3-319-22930-0_2.

24. Li, Z. et al. Combined silicon-phosphorus fertilization affects the biomass and phytolith stock of rice plants. Front. Plant Sci. 11, 67 (2020).

25. Meunier, J.-D., Sandhya, K., Prakash, N. B., Borschneck, D. \& Dussouillez, P. pH as a proxy for estimating plant-available Si? A case study in rice fields in Karnataka (South India). Plant Soil 432, 143-155 (2018).

26. Miles, N., Manson, A. D., Rhodes, R., van Antwerpen, R. \& Weigel, A. Extractable silicon in soils of the South African sugar industry and relationships with crop uptake. Commun. Soil Sci. Plant Anal. 45, 2949-2958 (2014).

27. Phonde, D. B., Deshmukh, P. S., Banerjee, K. \& Adsule, P. G. Plant available silicon in sugarcane soils and its relationship with soil properties, leaf silicon and cane yield. Asian J. Soil Sci. 9, 176-180 (2014).

28. Yanai, J., Taniguchi, H. \& Nakao, A. Evaluation of available silicon content and its determining factors of agricultural soils in Japan. Soil Sci. Plant Nutr. 62, 511-518 (2016).

29. Landré, A. et al. Do climate and land use affect the pool of total silicon concentration? A digital soil mapping approach of French topsoils. Geoderma 364, 114175 (2020).

30. Narayanaswamy, C. \& Nagabovanalli, P. Calibration and categorization of plant available silicon in rice soils of South India. J. Plant Nutr. 32, 1237-1254 (2009).

31. Babu, T., Tubana, B., Paye, W., Kanke, Y. \& Datnoff, L. Establishing soil silicon test procedure and critical silicon level for rice in Louisiana soils. Commun. Soil Sci. Plant Anal. https://doi.org/10.1080/00103624.2016.1194996 (2016).

32. Korndörfer, G., Snyder, G., Ulloa, M., Powell, G. \& Datnoff, L. Calibration of soil and plant silicon analysis for rice production. J. Plant Nutr. 24(7), 1071-1084 (2006).

33. Haysom, M. B. C. \& Chapman, L. S. Some aspects of the calcium silicate trials at Mackay. Proc. Queens. Soc. Sugar Cane Technol. 42, 117-122 (1975).

34. Clymans, W., Struyf, E., Govers, G., Vandevenne, F. \& Conley, D. J. Anthropogenic impact on amorphous silica pools in temperate soils. Biogeosciences 8, 2281-2293 (2011).

35. Datnoff, L. \& Rodrigues, F. The role of silicon in suppressing rice diseases. APSnet Features 58 (2005).

36. Desplanques, V. et al. Silicon transfers in a rice field in Camargue (France). J. Geochem. Explor. 88, 190-193 (2006).

37. Eneji, E. et al. Effect of calcium silicate on growth and dry matter yield of Chloris gayana and Sorghum sudanense under two soil water regimes. Grass Forage Sci. 60, 393-398 (2005).

38. Meunier, J. D., Guntzer, F., Kirman, S. \& Keller, C. Terrestrial plant-Si and environmental changes. Mineral. Mag. 72, 263-267 (2008).

39. Guntzer, F., Keller, C., Poulton, P. R., McGrath, S. P. \& Meunier, J.-D. Long-term removal of wheat straw decreases soil amorphous silica at Broadbalk, Rothamsted. Plant Soil 352, 173-184 (2012).

40. Watanabe, T., Luu, H. M., Nguyen, N. H., Ito, O. \& Inubushi, K. Combined effects of the continual application of composted rice straw and chemical fertilizer on rice yield under a double rice cropping system in the Mekong Delta, Vietnam. Jpn. Agric. Res. Q. 47, 397-404 (2013).

41. Barão, L. et al. Silicon mobilization in soils: the broader impact of land use. Silicon 12, 1529-1538 (2020).

42. Minasny, B., Mcbratney, A. \& Hartemink, A. Global pedodiversity, taxonomic distance, and the World Reference Base. Geoderma 155, 132-139 (2010).

43. Jolivet, C., Boulonne, L. \& Ratié, C. Manuel du Réseau de Mesures de la Qualité des Sols. (2006).

44. Mulder, V. L., Lacoste, M., Richer-de-Forges, A. C. \& Arrouays, D. GlobalSoilMap France: High-resolution spatial modelling the soils of France up to two meter depth. Sci. Total Environ. 573, 1352-1369 (2016).

45. Adhikari, K. et al. High-resolution 3-D mapping of soil texture in Denmark. Soil Sci. Soc. Am. J. 77, 860-876 (2013).

46. Padarian, J., Minasny, B. \& McBratney, A. B. Chile and the Chilean soil grid: A contribution to GlobalSoilMap. Geoderma Reg. 9, 17-28 (2017).

47. Loiseau, T. et al. Satellite data integration for soil clay content modelling at a national scale. Int. J. Appl. Earth Obs. Geoinf. 82, 101905 (2019).

48. Mehra, O. P. \& Jackson, M. L. Iron oxide removal from soils and clays by a dithionite-citrate system buffered with sodium bicarbonate. Clays Clay Miner. 7, 317-327 (1960).

49. Kaczorek, D., Puppe, D., Busse, J. \& Sommer, M. Effects of phytolith distribution and characteristics on extractable silicon fractions in soils under different vegetation-An exploratory study on loess. Geoderma 356, 113917 (2019).

50. Irfan, K. Impact of 60 years of intensive rice cropping on clay minerals in soils due to Si exportation. Am. J. Agric. For. 5, 40 (2017).

51. Nguyen, M. N. et al. Silicic acid as a dispersibility enhancer in a Fe-oxide-rich kaolinitic soil clay. Geoderma 286, 8-14 (2017).

52. Haynes, R. J. What effect does liming have on silicon availability in agricultural soils?. Geoderma 337, 375-383 (2019). 
53. Goldberg, S., Lebron, I., Seaman, J. C. \& Suarez, D. L. Soil colloidal behaviour. In Handbook of Soil Sciences (CRC, Taylor \& Francis [distributor], Boca Raton, 2011).

54. Cornu, S., Montagne, D., Hubert, F., Barré, P. \& Caner, L. Evidence of short-term clay evolution in soils under human impact. C. R. Geosci. 344, 747-757 (2012).

55. European Environment Agency. CLC2006 Technical Guidelines. (2007).

56. Landré, A. et al. Prediction of total silicon concentrations in French soils using pedotransfer functions from mid-infrared spectrum and pedological attributes. Geoderma 331, 70-80 (2018).

57. King, D., Daroussin, J. \& Tavernier, R. Development of a soil geographic database from the Soil Map of the European Communities. CATENA 21, 37-56 (1994).

58. McBratney, A. B., Mendonça Santos, M. L. \& Minasny, B. On digital soil mapping. Geoderma 117, 3-52 (2003).

59. Kursa, M. B. \& Rudnicki, W. R. Feature selection with the Boruta package. J. Stat. Softw. 36, 1-3 (2010).

60. Breiman, L. Random Forests. Mach. Learn. 45, 5-32 (2001).

61. Keskin, H. \& Grunwald, S. Regression kriging as a workhorse in the digital soil mapper's toolbox. Geoderma 326, $22-41$ (2018).

62. Hengl, T., Kempen, B., Heuvelink, G. B. M. \& Malone, B. P. GSIF: Global Soil Information Facilities. (2019).

63. Lin, L. I. K. A concordance correlation coefficient to evaluate reproducibility. Biometrics 45, 255-268 (1989).

64. Saby, N. P. A. et al. Données de réplication pour : Agriculture increases the bioavailability of silicon, a beneficial element for crop, in temperate soils. https://doi.org/10.15454/CFWBAA (2020).

\section{Acknowledgements}

This work was performed in the frame of the French ANR BioSiSol project (ANR-14-CE01-0002). RMQS soil sampling and physico-chemical analyses were supported by the GIS Sol, which is a scientific group of interest on soils involving the French Ministry for ecology and sustainable development and Ministry of agriculture, the French National forest inventory (IFN), ADEME, IRD and INRAE. The authors are grateful to Annie Guérin (LAS, INRAE, Arras, France) and Amélia Landré (INFOSOL, INRAE, Orléans, France) for $\mathrm{Si}_{\mathrm{CaCl} 2}$ analysis and database preparation respectively.

\section{Author contributions}

M.C. performed the data treatment and statistical analyses and contributed to the writing of the manuscript. N.S. contributed to the writing of the proposal, supervised M.C. in the data treatment methods and analysis, and contributed to the writing. S.C. and J.D.M. wrote the proposal and contributed to the interpretation of the data and to the manuscript writing.

\section{Competing interests}

The authors declare no competing interests.

\section{Additional information}

Supplementary information is available for this paper at https://doi.org/10.1038/s41598-020-77059-1.

Correspondence and requests for materials should be addressed to S.C.

Reprints and permissions information is available at www.nature.com/reprints.

Publisher's note Springer Nature remains neutral with regard to jurisdictional claims in published maps and institutional affiliations.

Open Access This article is licensed under a Creative Commons Attribution 4.0 International License, which permits use, sharing, adaptation, distribution and reproduction in any medium or format, as long as you give appropriate credit to the original author(s) and the source, provide a link to the Creative Commons licence, and indicate if changes were made. The images or other third party material in this article are included in the article's Creative Commons licence, unless indicated otherwise in a credit line to the material. If material is not included in the article's Creative Commons licence and your intended use is not permitted by statutory regulation or exceeds the permitted use, you will need to obtain permission directly from the copyright holder. To view a copy of this licence, visit http://creativecommons.org/licenses/by/4.0/.

(C) The Author(s) 2020 